\title{
ALIRAN BAHAN ORGANIK PADA SAWAH PADI ORGANIK DI DUSUN JAYAN DESA KEBONAGUNG KEC. IMOGIRI KAB. BANTUL D.I. YOGYAKARTA
}

\author{
Arif Anshori $^{1)}$, Bambang Hendro Sunarminto ${ }^{2)}$ dan Eko Haryono ${ }^{3)}$ \\ 1) BPTP Yogyakarta ; Mahasiswa Program Doktor Ilmu Lingkungan UGM \\ email : arifanshori@yahoo.com \\ ${ }^{2)}$ Departemen Tanah Fakultas Pertanian UGM \\ ${ }^{3)}$ Departemen Geografi Lingkungan Fakultas Geografi UGM
}

\begin{abstract}
Organic farming uses natural resources to improve the health and productivity of soil and plants. Nutrients are lost or transported through crops, erosion, leaching and volatilization must be replaced naturally and through the return of organic matter. This research aims to study the conditions of organic rice fields, specifically in terms of organic matter flow, in Jayan Kebonagung Imogiri Bantul. The organic rice field data obtained from interviews and archive farmers. The results indicate that the organic rice field in Jayan under a transition from conventional to organic rice field. Dose of organic fertilizer 10 tons/ha were given during the transition period. Organic fertilizer 5-10 tons/ha have been giving during the organic rice fields. Returns organic matter to agricultural land through land-cropland, land-plant-livestock-land and land-crop-livestock-biogas-land. Manure, weeds and paddy field plants, crop waste, waste from agricultural products processing and non-agricultural organic wastes involved in the flow of organic matter. Farmers monitor the health and productivity of soil and plants as the basis in the management of organic rice field.
\end{abstract}

Kata kunci : organic matter flow, organic rice field

\section{PENDAHULUAN}

Pertanian organik merupakan pilihan untuk memperoleh hasil dan kondisi lingkungan sehat dengan menghindarkan pemakaian bahan kimia sintetis yang bersifat racun. Pertanian organik memanfaatkan sumberdaya alami untuk memperbaiki produktivitas dan kesehatan tanah dan tanaman. Manusia berperan penting dalam mengelola sumberdaya alami berdasarkan prinsip produktivitas, kesehatan dan keberlanjutan.

Praktek pertanian organik dijalankan dengan mengembalikan hasil pertanian, sisa hasil pertanian, limbah hasil pertanian, pupuk hijau maupun gulma melalui proses pendauran ulang. Pertanian organik dapat memberikan nilai tambah dari segi produktivitas dan kesehatan tanah dan tanaman, serta keberlanjutan ekosistem.

Secara prinsip, aliran hara harus terjadi secara konstan. Unsur hara yang hilang atau terangkut melalui hasil panen, erosi, pelindian dan volatilisasi harus digantikan. Untuk mempertahankan sistem usahatani tetap produktif dan sehat, maka jumlah hara yang hilang dari dalam tanah tidak melebihi hara yang ditambahkan, atau harus terjadi keseimbangan hara di dalam tanah setiap waktu. Apabila hara yang diekstrak dari dalam tanah lebih banyak dari pada yang ditambahkan melalui proses alami seperti melalui debu dan air hujan, pelapukan batuan dan penambatan nitrogen udara, maka teknik pemupukan organik, mendaur ulang limbah organik dikombinasikan dengan pemupukan kimia diperlukan untuk mempertahankan aras kesuburan tanah (Sutanto, 2002).

Kondisi ini sangat berhubungan erat dengan daur dan aliran bahan organik. Pengembalian bahan organik ke lahan pertanian melalui lahan-tanaman-lahan atau lahan-tanaman-ternak-lahan atau yang lain. Bahan organik masuk ke lahan melalui ternak atau langsung ke lahan. Kehilangan hara saat bahan organik terangkut panen diimbangi dengan pemasukan bahan organik dari luar lahan.

Penelitian ini bertujuan untuk mempelajari daur dan aliran bahan organik pada sawah padi organik di Dusun Jayan. Penelitian ini merupakan penggalian data lapangan melalui wawancara dan arsip petani. 


\section{METODE PENELITIAN}

Penelitian dilaksanakan di Dusun Jayan Desa Kebonagung Kec. Imogiri Kab. Bantul D.I. Yogyakarta pada bulan Pebruari tahun 2015. Data menyangkut kondisi sawah padi organik diperoleh dari wawancara dan arsip petani. Wawancara melibatkan 3 orang petani kunci yang aktif pada sawah padi organik. Arsip yang diperoleh berupa laporan, catatan lepas dan foto. Data yang telah terkumpul selanjutnya digunakan sebagai dasar untuk mendeskripsikan sawah padi organik di Dusun Jayan. Tinjauan hasil penelitian terkait sawah padi organik digunakan sebagai pendukung dalam memahami aliran bahan organik pada sawah padi organik di Dusun Jayan.

\section{HASIL DAN PEMBAHASAN}

Kontribusi penting bahan organik dalam keberlanjutan dibandingkan sifat tanah yang lain adalah karena mampu mempengaruhi banyak fungsi tanah. Bahan organik mempengaruhi sifat biologi, kimia dan fisik bahan tanah itu sendiri. Konsep kualitas tanah telah terbukti bermanfaat dalam upaya mengukur peran tanah dalam memberikan kontribusi bagi penggunaan lahan berkelanjutan. Dengan demikian, kualitas sebuah tanah yang dinilai untuk menyimpan air berbeda dengan tanah yang sama ketika dinilai kualitasnya untuk tujuan yang lain. Namun, salah satu fitur penting tanah dan bahan organik yang dikandungnya adalah kemampuan untuk bertindak sebagai sistem kehidupan. Untuk itu, istilah kesehatan tanah dapat digunakan untuk mendefinisikan kapasitas tanah sebagai sistem kehidupan dalam ekosistem dan batas-batas bentang lahan, untuk mempertahankan produktivitas biologis, untuk meningkatkan kualitas lingkungan udara dan air untuk mendukung aktivitas biologis dan mengelola kesehatan tanaman, hewan dan manusia (Agus, 2012).

Bahan organik tanah merupakan dasar kuat untuk menghasilkan tanah yang sehat dan produktif. Memahami peran bahan organik dalam mempertahankan tanah yang sehat sangat penting untuk mengembangkan praktek pertanian yang ramah lingkungan. Bahan organik merupakan pokok, walaupun bukan merupakan satu-satunya bagian. Bahan organik berperan besar dalam sejumlah proses kunci dalam pertumbuhan tanah dan tanaman, serta menjadi bagian penting dari sejumlah siklus global dan regional (Magdoff and Van Es, 2009). Bahan organik berperan besar dalam sifat biologi, kimia dan fisik tanah, sangat penting untuk menghasilkan tanah dan tanaman yang sehat (Gambar 1).

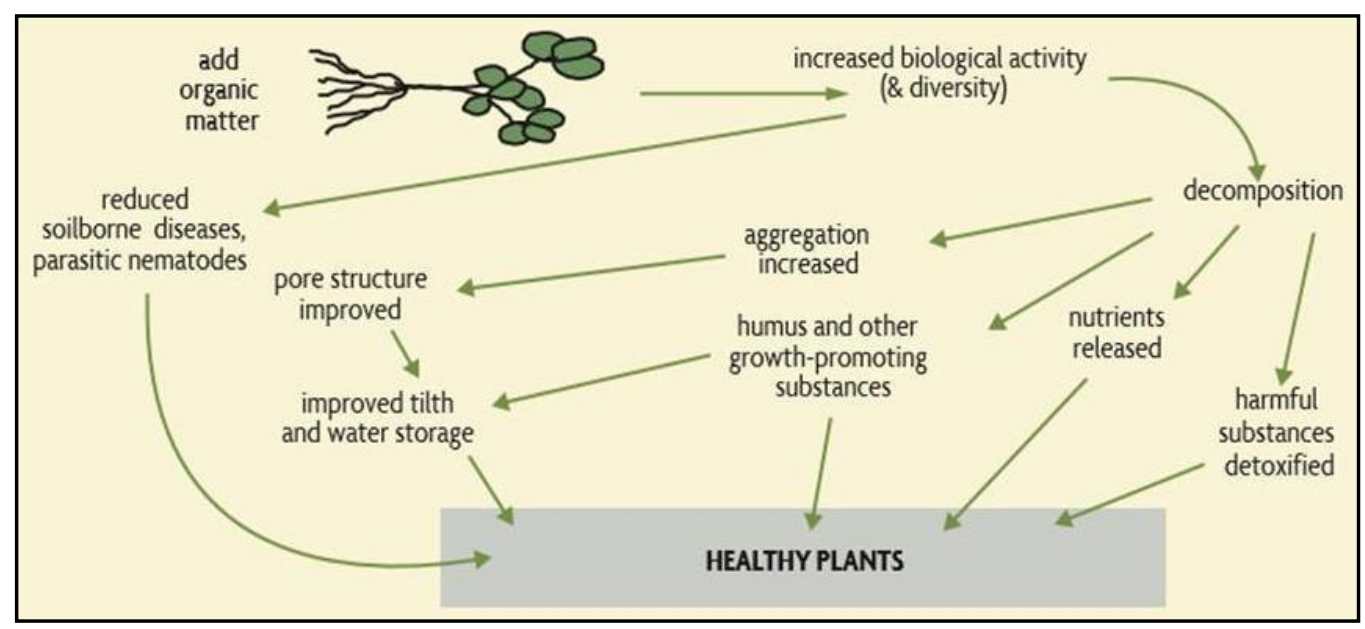

Gambar 1. Penambahan bahan organik menghasilkan tanaman sehat.

Sumber : Magdoff and Van Es, 2009.

Bahan organik berperan dalam pembentukan struktur dan agregat tanah yang baik, sehingga akan memperbaiki kondisi fisik tanah. Selanjutnya, secara tidak lagsung, bahan organik mempermudah penetrasi akar, perkembangan akar, serta meningkatkan ketahanan tanah terhadap erosi. Bahan organik meningkatkan kapasitas pertukaran kation dan daya sangga tanah, fototoksisitas, keterlindian, serta biodegredasi pestisida dalam tanah. Bahan organik membentuk kompleks dengan unsur hara mikro sehingga mencegah kehilangan melalui pelindian serta keracunan. 
Bahan organik meningkatkan ketersediaan posfor dalam tanah (Sanchez, 1976).

Ketersediaan nutrisi utama dalam tanah dipengaruhi oleh kehadiran bahan organik tanah (Magdoff and Van Es, 2009). Bahan organik tanah membentuk cadangan nutrisi tersedia melalui mineralisasi dan desorpsi, serta mengikat nutrisi melalui reaksi imobilisasi dan adsorpsi (Gambar 2). Nasib nutrisi sangat tergantung pada proses yang mempengaruhi pembentukan dan dekomposisi bahan organik tanah. Strategi pengelolaan yang bertujuan menghasilkan akumulasi bahan organik tanah untuk ketersediaan hara secara berkelanjutan harus membuat suatu kondisi lingkungan yang menguntungkan bagi mikro fauna dan flora tanah karena berperan secara dominan dalam proses mineralisasi dan imobilisasi (Seiter and Horwath, 2009). Proses dekomposisi dikendalikan terutama oleh bakteri dan jamur (Scow, 1997). Mikrofauna seperti protozoa, nematoda, dan cacing tanah juga memainkan peran utama dalam siklus hara dan terlibat dalam mineralisasi nutrisi (Coleman, et al, 2004).

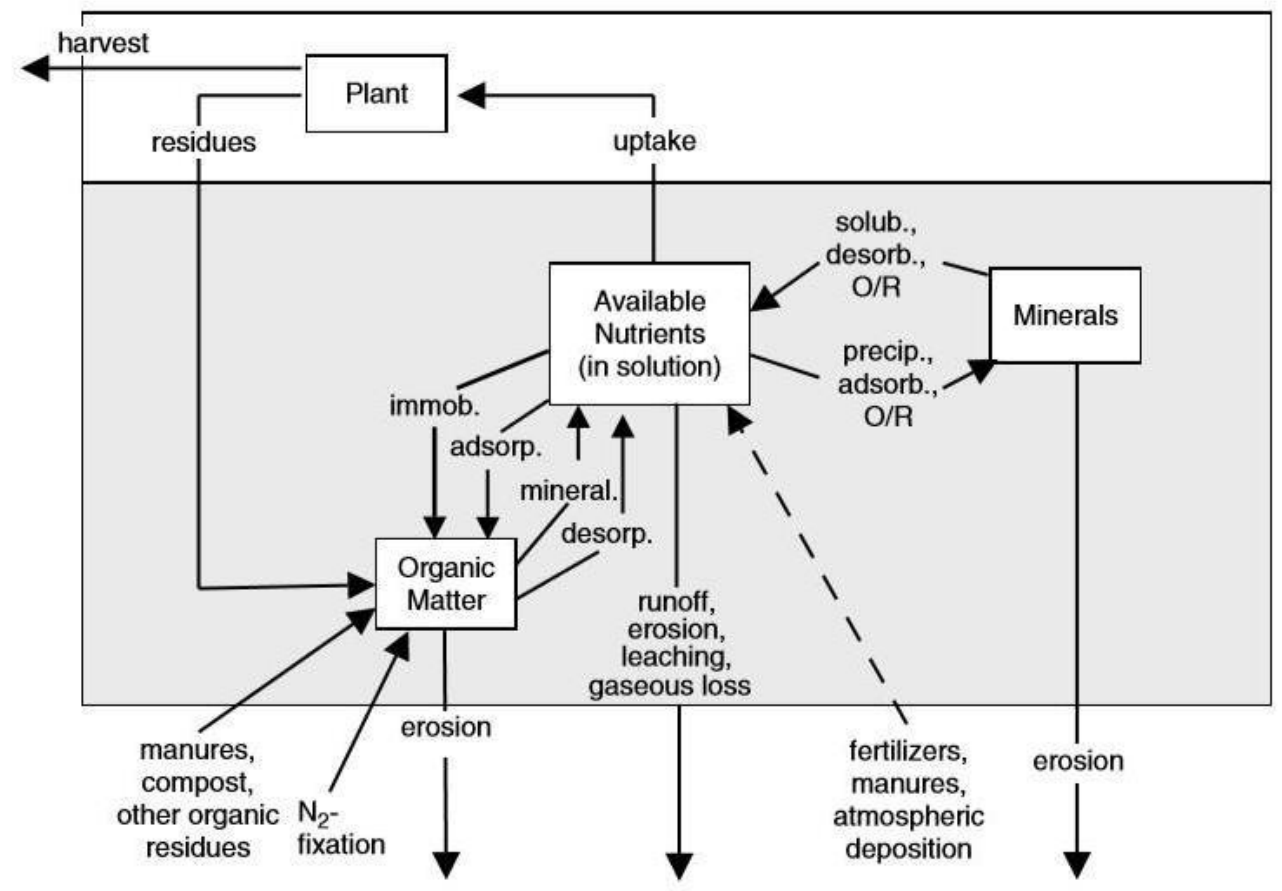

Gambar 2. Aliran hara dan biomassa dalam sistem tanah-tanaman.

Sumber : Seiter and Horwath, 2009

Tujuan pengelolaan agroekosistem secara berkelanjutan adalah terakumulasi dan terpeliharanya bahan organik tanah (Magdoff and Van Es, 2009). Pengelolaan bahan organik tanah, menghasilkan akumulasi, perbaikan kualitas dan kesehatan tanah serta ketersediaan hara. Bahan organik tanah tinggi akan meningkatkan porositas, mendorong perkembangan dan distribusi akar, serta diikuti dengan meningkatknya penyerapan nutrisi oleh tanaman.

Petani sawah padi organik Dusun Jayan dalam membangun kesehatan dan produktivitas tanah dan tanaman, telah memalui proses panjang dan mengalami transisi dari pertanian sawah padi konvensional ke organik (Gambar 3). Pertanian sawah padi konvensional mengandalkan pupuk kimia sintetis, sementara sawah padi organik mengandalkan pengembalian bahan organik. Usaha membangun kesuburan tanah dilakukan dengan memberikan bahan organik melalui berbagai sumber, diantaranya adalah kompos, gulma dan tumbuhan sawah lain, limbah pertanian, limbah pengolahan hasil pertanian dan limbah organik non pertanian. 


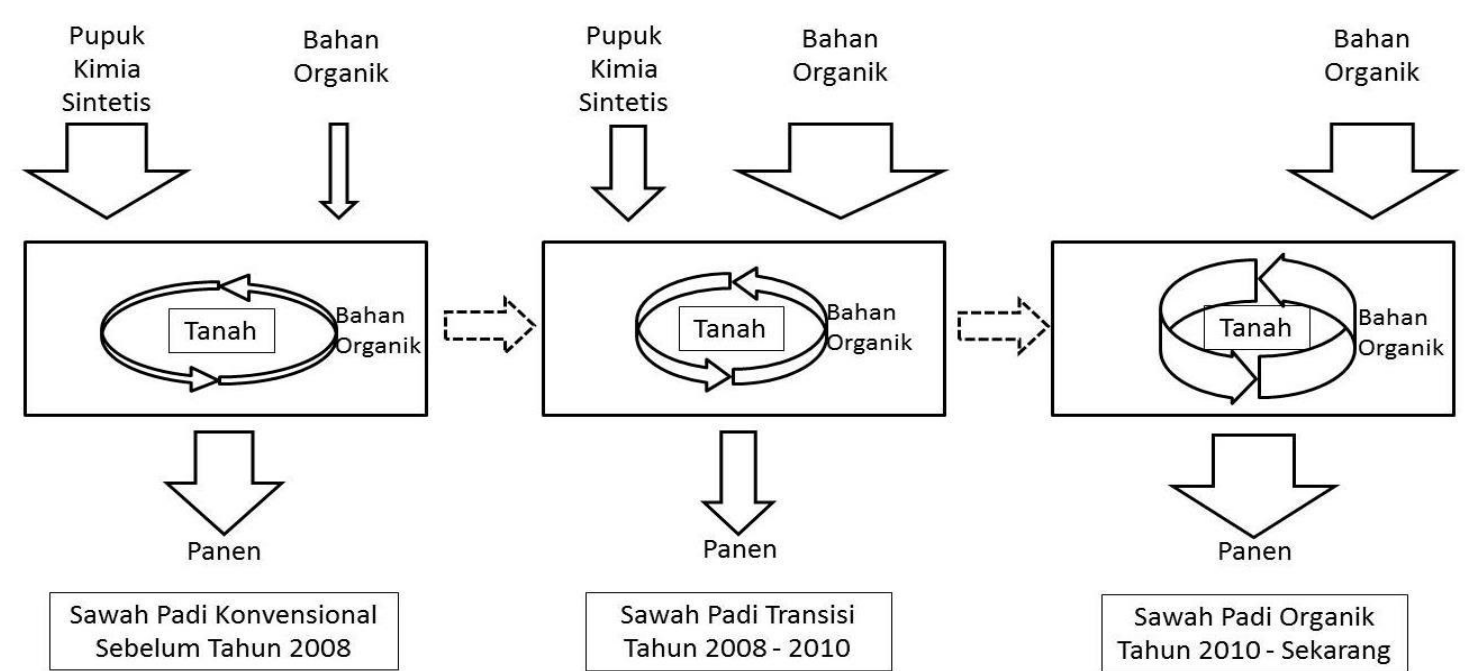

Gambar 3. Ilustrasi pemakaian bahan organik pada sawah padi konvensional-transisiorganik di Dusun Jayan.

Pupuk organik diberikan dalam jumlah sangat sedikit pada masa sawah padi konvensional, petani mengandalkan pupuk kimia sintetis. Pada masa transisi, pupuk organik diberikan dalam jumlah tinggi, mencapai dosis 10 ton/ha. Dosis pupuk kimia sintetis mengalami penurunan drastis pada masa transisi, diganti dengan pemakaian bahan organik. Pupuk kimia sintetis tidak diberikan lagi pada masa sawah padi organik, petani sudah mengandalkan bahan organik. Dosis pupuk organik pada sawah padi organik berkisar $5-10$ ton/ha. Perputaran bahan organik dalam tanah meningkat.

Pupuk organik berfungsi memperbaiki sifat fisik, kimia dan biologi tanah, menyediakan unsur hara bagi tanaman, yang selanjutnya meningkatkan kesehatan dan produktivitas tanah dan tanaman. Pengembalian bahan organik ke lahan pertanian pada sawah padi organik di Dusun Jayan melalui jalur lahan-tanaman-lahan, lahan-tanaman-ternak-lahan dan lahantanaman-ternak-biogas-lahan (Gambar 4).

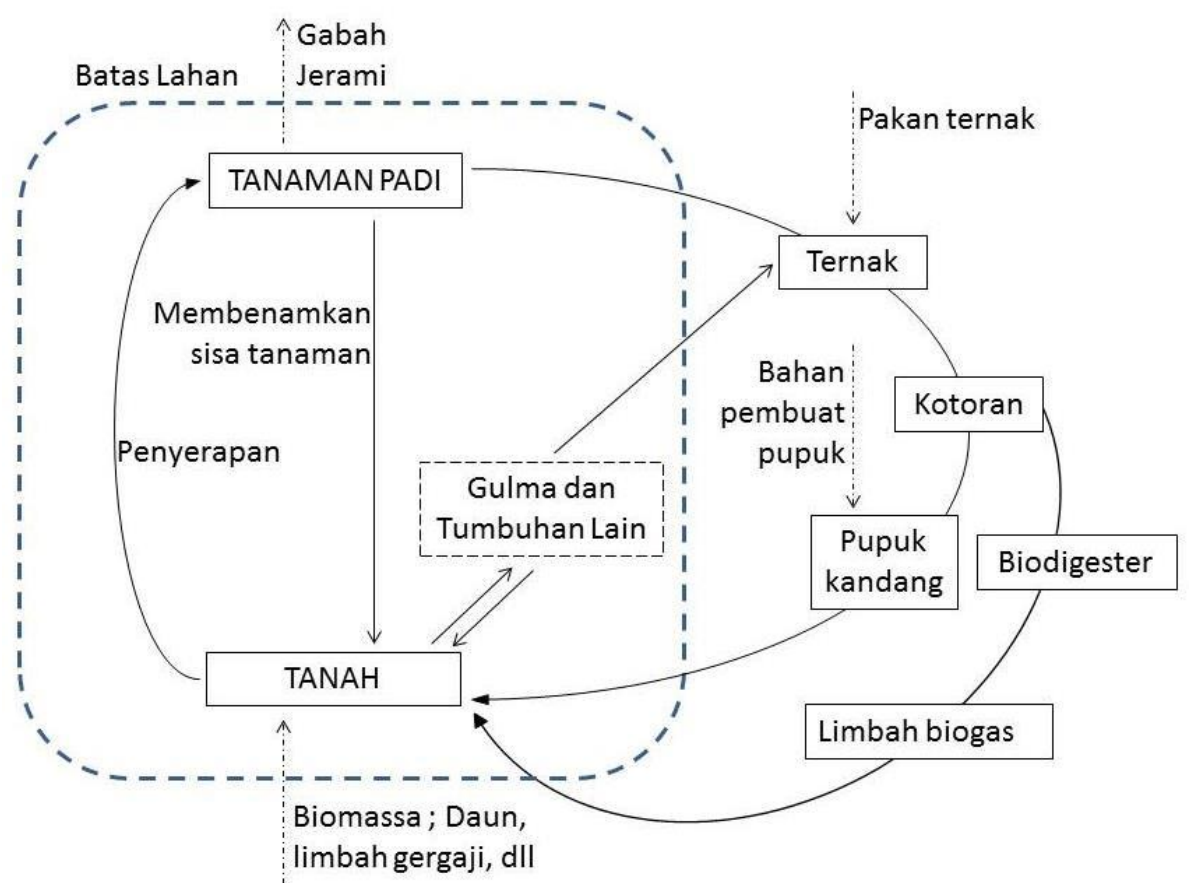

Gambar 4. Aliran bahan organik pada sawah padi organik di Dusun Jayan. 
Bahan organik kemungkinan hilang dari lahan karena pergi melampaui batas lahan, baik melalui proses pengelolaan atau tidak. Pada sawah padi organik Dusun Jayan bahan organik hilang saat hasil panen berupa gabah dan jerami. Gabah dijual karena bernilai ekonomi. Jerami diambil sebagai pakan ternak sampai melampaui batas lahan.

Bahan organik dari luar lahan dapat masuk melalui pakan ternak ke lahan dalam bentuk kotoran, kompos atau limbah biogas, Kondisi ini mengimbangi perginya bahan organik melampaui batas lahan. Bahan pembuat pupuk organik juga dapat menjadi penyumbang bahan organik dari luar lahan.
Daur dan aliran bahan organik terjadi melalui pupuk kandang, limbah pertanaman, gulma, limbah pengolahan hasil pertanian dan limbah organik non pertanian. Daur ulang dilakukan dengan cara mengembalikan langsung ke lahan sawah, melalui proses pengomposan atau fermentasi biogas.

Petani sawah padi organik Dusun Jayan memantau kondisi kesehatan dan produktivitas tanah dan tanaman. Hasil pemantauan dijadikan sebagai dasar dalam melaksanakan pengelolaan pada musim tanam yang sedang berlangsung dan musim tanam berikutnya (Gambar 5).

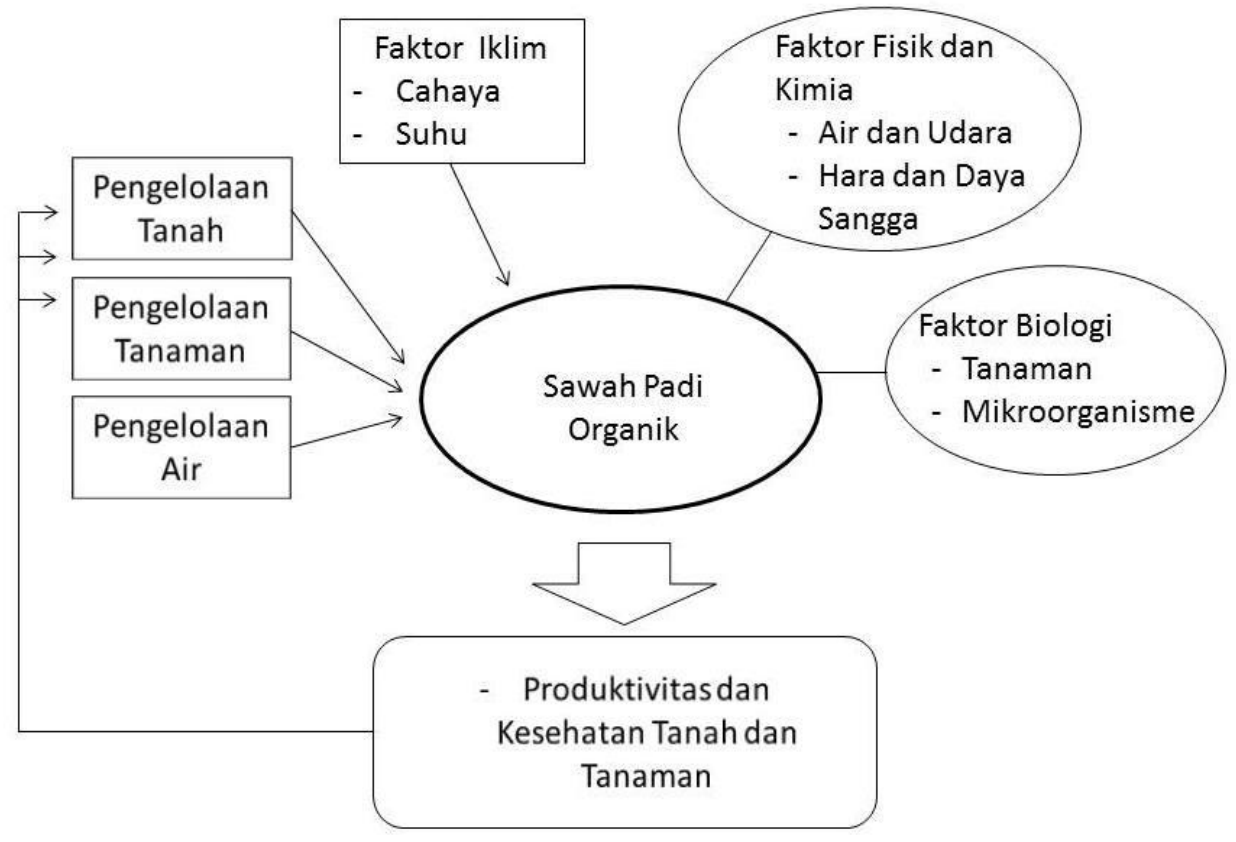

Gambar 5. Siklus pengelolaan sawah padi organik untuk mempertahankan produktivitas dan kesehatan tanah dan tanaman di Dusun Jayan.

Beberapa parameter menjadi perhatian petani dalam memantau produktivitas dan kesehatan tanah dan tanaman adalah serangan hama dan atau penyakit, musuh alami hama dan atau penyakit, abnormalitas pertumbuhan dan perkembangan tanaman, keberadaan cacing tanah dan atau hewan sawah lain serta produktivitas tanaman. Hasil yang diperoleh dari beberapa parameter tersebut menjadi indikasi tingkat produktivitas dan kesehatan tanah dan tanaman, yang selanjutnya digunakan sebagai dasar dalam melakukan pengelolaan baik tanah, tanaman maupun air, pada musim tanam yang sedang berlangsung maupun musim tanam berikutnya.

\section{KESIMPULAN}

Sawah padi organik Dusun Jayan dibangun berdasarkan potensi sumberdaya pertanian setempat. Petani mengandalkan bahan organik untuk membangun produktivitas dan kesehatan tanah dan tanaman. Bahan organik yang diberikan berupa kompos, gulma dan tumbuhan sawah lain, limbah pertanian, limbah pengolahan hasil pertanian dan limbah organik non pertanian. Pengembalian bahan organik ke lahan sawah padi organik melalui jalur lahantanaman-lahan, lahan-tanaman-ternak-lahan dan lahan-tanaman-ternak-biogas-lahan. 


\section{DAFTAR PUSTAKA}

Agus, C. 2012. Pengelolaan bahan organik : peran dalam kehidupan dan lingkungan. BPFE-UGM. Yogyakarta

Coleman, D.C., D.A. Crossley Jr., P.F. Hendrix. 2004. Fundamentals of Soil Ecology. Academic Press. San Diego.

Magdoff, F. and H. Van Es. 2009. Building soils for better crops : Sustainable soil management. Sustainable Agriculture Research and Education (SARE) program - U.S. Department of Agriculture.

Sanchez, P.A. 1976. Properties and management of soils in the tropics. John Wiley and Sons. New York.
Scow, K.M. 1997. Soil microbial communities and carbon flow in agroecosystems. In : Jackson, L.E. (Eds.). Ecology in Agriculture. Academic Press. San Diego. p. 367-413.

Seiter, S. and W.R. Horwath. 2009. Strategies for Managing Soil Organik Matter to Supply Plant Nutrients. In : Magdoff, F and R.R. Weil (Eds.). Soil organik matter in sustainable agriculture. CRC Press. New York.

Sutanto, R. 2002. Pertanian organik : Menuju pertanian alternatif dan berkelanjutan. Penerbit Kanisius. Yogyakarta. 